\title{
Daya Terima Minuman Sari Buah Pisang Tongka Langit dengan Perlakuan Lama Blansing
}

\author{
Acceptance of Tongka Langit Banana Juice Drink Treated with Different Blanching Time
}

\author{
Vita N. Lawalata*, Gilian Tetelepta
}

Jurusan Teknologi Hasil Pertanian Fakultas Pertanian Universitas Pattimura

Jl. Ir. M. Putuhena Kampus Poka Ambon 97233

*Penulis Korespondensi: E-mail: vitalawalata@yahoo.com

\begin{abstract}
Tongka langit banana is one of specific local fruits in Maluku Province, and is potential to be developed due to its good nutritional contents. The purpose of this research was to determine the exact blanching time on the acceptance of tongka langit banana juice drink. An experimental research with different blanching time, i.e 5, 10, 15, and 20 minutes replicated twice was applied in this study. Results showed that tongka langit banana juice drink treated with 5-minute blanching time had the best acceptance level sensorically, that is yellow in colour (3.23), had banana like taste (3.14), no off flavour aroma (1.46), had aroma almost like banana (2.86) and a little bit cloudy (2.17).
\end{abstract}

Keywords: acceptance, blanching, fruit juice, tongka langit banana

\begin{abstract}
ABSTRAK
Pisang tongka langit merupakan salah satu jenis buah lokal yang khas di Provinsi Maluku, dan berpotensi dikembangkan karena memiliki nilai nutrisi yang baik. Tujuan penelitian ini untuk menentukan lama blansing yang tepat terhadap daya terima minuman sari buah pisang tongka langit. Penelitian ini merupakan penelitian eksperimental dengan perlakuan lama blansing 5, 10, 15, dan 20 menit, yang diulang sebanyak dua kali. Hasil penelitian menunjukkan bahwa Minuman sari buah pisang tongka langit dengan perlakuan lama blansing 5 menit memiliki tingkat penerimaan terbaik secara organoleptik, yaitu warna kuning $(3,23)$, berasa pisang $(3,14)$, tidak beraroma langu $(1,46)$, mendekati beraroma pisang $(2,86)$, dan agak keruh (2.17).
\end{abstract}

Kata kunci: blansing, daya terima, sari buah, pisang tongka langit

\section{PENDAHULUAN}

Pisang merupakan salah satu jenis buah yang melimpah dan banyak tersebar dan dijumpai di seluruh daerah di Indonesia. Khusus di daerah Maluku, terdapat salah satu jenis buah pisang lokal yang cukup khas dan berpotensi untuk dikembangkan yaitu pisang tongka langit (Musa troglodytarum). Pisang tongka langit terdiri dari dua jenis yaitu pisang tongka langit dengan ukuran buah lebih pendek (Gambar 1) dan pisang tongka langit dengan ukuran buah yang lebih panjang (Gambar 2).
Pisang ini memiliki karbohidrat yang tinggi, protein, lemak, dan juga banyak mengandung mineral dan vitamin. Hasil penelitian Samson et al. (2011), menunjukkan bahwa pisang tongka langit baik yang ukuran panjang maupun pendek, memiliki kandungan total karotenoid seperti $\alpha$ karoten, $\beta$-karoten, zeaxantin serta lutein. Diantara pigmen-pigmen karotenoid tersebut, yang paling dominan adalah $\beta$-karoten yang merupakan sumber provitamin A. $\beta$-karoten memiliki efisiensi $100 \%$ untuk diubah menjadi vitamin A (Nasruddin dan Limantara, 2008), dan vitamin A sangat essensial untuk pertumbuhan, karena merupakan senyawa penting dalam meningkatkan sistem daya tahan 
tubuh sehingga membuat tubuh tahan terhadap infeksi dan juga sangat bermanfaat dalam mencegah kebutaan.

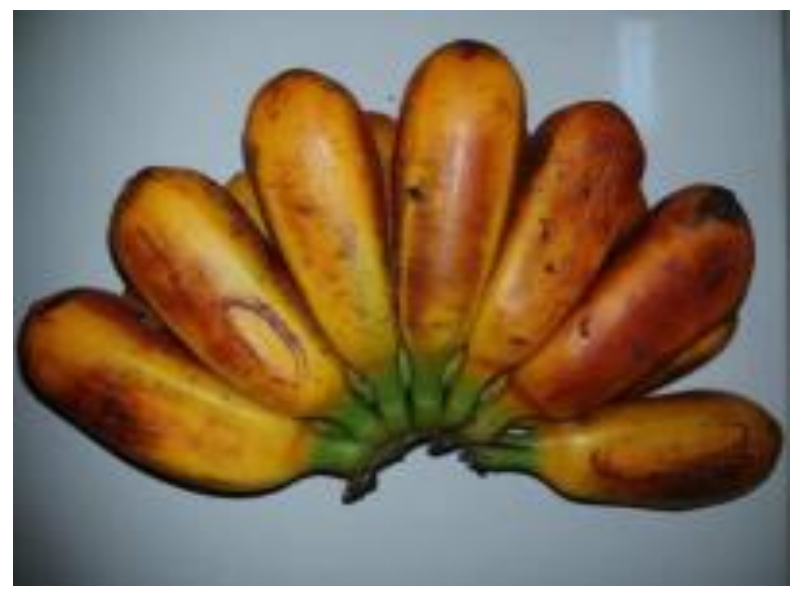

Gambar 1. Pisang tongka langit ukuran pendek

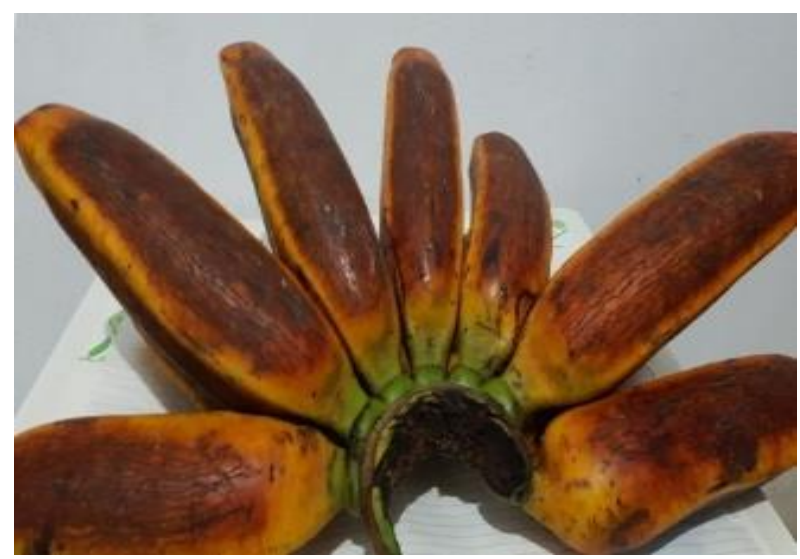

Gambar 2. Pisang tongka langit ukuran panjang

Pisang tongka langit merupakan salah satu buah yang cepat rusak dan akan membusuk 10 hari setelah di panen, sehingga perlu adanya upaya untuk mempertahankan daya simpan pisang tersebut. Oleh karena itu, diperlukan pengolahan pasca panen untuk mempertahankan komponen gizi dan memperpanjang umur simpannya. Salah satu cara untuk mempertahankan daya simpan, meningkatkan permintaan serta daya guna buah pisang tongka langit adalah dengan mengolahnya menjadi produk minuman sari buah pisang. Selain lebih tahan lama, pengolahan ini akan membuat rasa pisang bervariasi.

Pembuatan sari buah pisang tongka langit dengan penambahan air dan dipanaskan yang dilakukan sebelumnya oleh Lawalata dan Tetelepta (2017) menghasilkan sari buah pisang yang masih beraroma langu sehingga rasa pisang tidak terasa dan mempengaruhi penerimaan konsumen terhadap rasa sari buah pisang tongka langit tersebut. Untuk mendapatkan suatu teknologi pengolahan sari buah pisang tongka langit yang dapat menghilangkan aroma dan rasa langu, maka perlu dilakukan beberapa perlakuan pengolahan sehingga diharapkan dapat menghasilkan sari buah pisang tongka langit yang bermutu dan disukai oleh konsumen.

Teknologi pengolahan yang dapat diaplikasikan untuk menghilangkan bau dan rasa langu dari sari buah pisang tongka langit adalah proses blansing. Blansing merupakan suatu proses pemanasan pendahuluan pada suhu kurang dari $100^{\circ} \mathrm{C}$ selama beberapa menit terhadap bahan yang akan diolah. Proses blansing dapat dilakukan dengan perendaman dalam air panas atau menggunakan uap panas dengan tujuan menginaktifkan enzim-enzim oksidatif yang dapat mengakibatkan perubahan warna, bau, citarasa, dan tekstur. Beberapa hasil penelitian menunjukkan bahwa perlakuan blansing dapat mempertahankan warna, aroma, flavor, dan tekstur dari bahan pangan yang diolah seperti tepung kimpul, kunir putih, dan manisan sawi (Ayu dan Yuwono, 2014; Pujimulyani et al., 2010; Siregar et al., 2005).

Perlakuan lama blansing diharapkan dapat menghilangkan rasa langu dari sari buah pisang tongka langit, sehingga dapat meningkatkan daya terima panelis. Tujuan penelitian ini adalah untuk menentukan lama blansing yang tepat terhadap daya terima minuman sari buah pisang tongka langit.

\section{METODE PENELITIAN}

\section{Bahan}

Bahan utama yang digunakan dalam penelitian ini adalah buah pisang tongka langit ukuran panjang dengan tingkat kematangan masak fisiologis yaitu seluruh bagian kulit buah berwarna oranye dan bertekstur agak lembek. Bahan tambahan adalah gula pasir, akuades, natrium benzoat, dan asam sitrat.

\section{Pelaksanaan Penelitian}

Metode penelitian yang digunakan adalah metode eksperimental yaitu perlakuan lama blansing (5, 10, 15, dan 20 menit) dengan dua kali ulangan. Proses penelitian adalah sebagai berikut, buah pisang tongka langit disortasi untuk memilih 
buah yang baik untuk diolah menjadi sari buah dan memiliki ukuran seragam. Buah pisang dicuci bersih dan dikeringanginkan, kemudian di blansing sesuai perlakuan. Setelah diblansing, dilakukan pengupasan, dan daging buah pisang dipotong menjadi kecil-kecil dengan ukuran yang seragam. Selanjutnya dilakukan pemasakan daging buah di dalam air mendidih selama 5 menit, dengan perbandingan buah pisang dan air adalah 1:5. Kemudian dilakukan penyaringan yang bertujuan untuk memisahkan sari buah dengan potongan pisang. Hasil penyaringan berupa sari buah dipanaskan kembali selama 2 menit sambil ditambahkan bahan-bahan tambahan yaitu gula pasir $12,5 \%$, natrium benzoat $0,05 \%$, dan asam sitrat $0,1 \%$. Kemudian dilakukan penyaringan lagi. Sari buah yang dihasilkan dibiarkan beberapa menit sehingga dingin, dan kemudian dilakukan pengujian daya terima panelis menggunakan metode pengujian organoleptik (Setyaningsih et al., 2010) yaitu uji mutu hedonik terhadap sifat inderawi warna, rasa, aroma pisang, aroma langu, dan kekeruhan. Panelis yang digunakan adalah panelis semi terlatih sebanyak 30 panelis, yang diminta memberikan penilaian pada font penilaian yang tersedia.

\section{Analisis Data}

Data hasil penelitian dianalisis secara statistik menggunakan analisis keragaman, bila terdapat perbedaan yang nyata atau sangat nyata maka pengujian dilanjutkan dengan uji beda nyata jujur pada taraf $95 \%$.

\section{HASIL DAN PEMBAHASAN}

Pengujian organoleptik dilakukan untuk mengetahui daya terima atau tingkat penerimaan panelis terhadap produk sari buah pisang tongka langit yang dihasilkan. Hasil penelitian dan penilaian panelis sari buah pisang tongka langit dari berbagai perlakuan lama blansing disajikan pada Gambar 3 dan Tabel 1.

Hasil penilaian panelis terhadap warna sari buah pisang tongka langit yang disajikan pada Tabel 1, berkisar antara 2,43-3,23 yang secara deskriptif menunjukkan warna agak kuning sampai kuning. Semakin lama blansing, warna sari buah pisang tongka langit yang dihasilkan menunjukkan warna kuning yang semakin pudar (agak kuning). Hal ini dikarenakan perlakuan lama blansing dan adanya penambahan asam sitrat pada pembuatan sari buah dapat menghambat terjadinya proses browning dimana proses browning menyebabkan warna pudar sari buah akan berubah menjadi pekat. Hasil yang sama juga ditunjukkan oleh Mao et al. (2007), yang menyatakan proses blansing dan penambahan asam askorbat menghalangi terjadinya browning pada sari buah tebu.

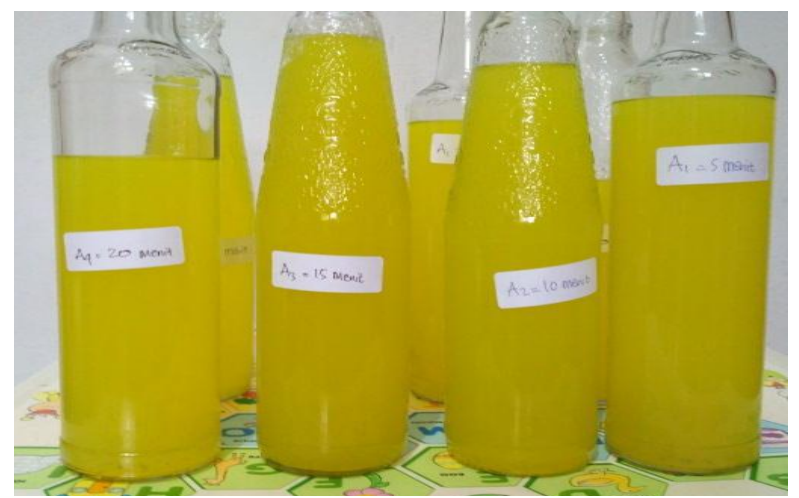

Gambar 3. Sari buah pisang tongka langit

Penurunan penilaian panelis terhadap warna sari buah pisang tongka langit juga dipengaruhi oleh adanya kandungan karotenoid yang terdapat pada pisang tongka langit, dimana karotenoid merupakan salah satu pigmen penting yang menyumbang warna kuning pada produk pisang. Menurut Samson et al. (2013), perlakuan lama blansing mengakibatkan karotenoid teroksidasi dan mengalami kerusakan sehingga diduga akan menyebabkan warna kuning pada sari buah pisang tongka langit semakin pudar.

Penilaian panelis terhadap rasa sari buah pisang tongka langit pada Tabel 1 , berkisar antara 2,57-3,14 yang secara deskriptif menunjukkan agak berasa pisang hingga berasa pisang. Semakin lama perlakuan blansing, rasa khas pisang tongka langit pada sari buah yang dihasilkan semakin menurun. Rasa khas pisang tongka langit pada sari buah berkaitan erat dengan aroma yang dihasilkan, dimana perlakuan lama blansing menyebabkan menurunnya aroma khas pisang tongka langit sehingga mempengaruhi penilaian panelis terhadap rasa pisang tongka langit.

Aroma bahan pangan umumnya disebabkan oleh bahan kimia atau membentuk persenyawaan dengan bahan lain (Soekarto, 1985; Kartika et al., 1988) dan menentukan kelezatan bahan pangan tersebut. Hasil penilaian panelis terhadap aroma sari buah pisang cenderung menurun dengan meningkatnya perlakuan lama blansing, yaitu berkisar antara 2,86-2,46 yang secara deskriptif 
menunjukkan mendekati beraroma pisang sampai agak beraroma pisang. Hal ini disebabkan semakin lama perlakuan blansing, maka senyawa volatil yang terdapat pada sari buah semakin rusak dan hilang akibat kontak dengan panas, flavor yang secara alami terdapat pada buah-buahan seringkali hilang selama proses pengolahan khususnya proses pemanasan. Selain pengaruh dari senyawa volatil yang terkandung dari buah pisang, aroma sari buah pisang dipengaruhi oleh pengaruh glukosa dan fruktosa.

Pengertian langu menurut Kamus Besar Bahasa Indonesia adalah bau atau rasa yang tidak sedap (Departemen Pendidikan Indonesia, 2008). Aroma langu pada suatu produk pangan dapat mempengaruhi kesukaan konsumen dalam mengonsumsi produk tersebut. Berdasarkan tabel 1 , terlihat bahwa penilaian panelis terhadap aroma langu sari buah pisang tongka langit berkisar antara 1,09-1,46 yang secara deskriptif tidak menunjukkan adanya aroma langu. Tidak terdeteksinya aroma langu pada sari buah pisang tongka langit disebabkan karena blansing merupakan salah satu teknik pemanasan yang dapat memperbaiki aroma yang tidak diinginkan. Blansing yang dilakukan tanpa tutup memberikan efek hilangnya aroma khas langu dari bahan tersebut. Penguapan yang terjadi pada pemanasan menyebabkan aroma spesifik bahan sulit dipertahankan (Puspasari, 2009). Selain itu menurut Aini (2016) dengan adanya penambahan sukrosa (gula pasir) pada pembuatan sari buah maka aroma langu semakin tertutupi oleh aroma dari gula.

Kekeruhan merupakan banyaknya partikel bahan yang tersuspensi pada suatu larutan. Kekeruhan pada minuman sari buah disebabkan oleh adanya senyawa protein, pektin dan tannin yang terdispersi koloid di dalam minuman tersebut. Hasil penilaian panelis terhadap kekeruhan sari buah pisang tongka langit berkisar antara 1.86-2.17 yang secara deskriptif menunjukkan tidak keruh hingga agak keruh (Tabel 1). Hasil penilaian panelis memperlihatkan bahwa semakin lama blansing sari buah pisang tongka langit yang dihasilkan semakin tidak keruh. Penurunan nilai kekeruhan akibat perlakuan lama blansing pada sari buah disebabkan tidak terlewatnya koloid, partikel ataupun padatan-padatan pada proses blansing sari buah pisang tongka langit, sehingga sari buah pisang tongka langit hasil blansing memiliki suspensi partikel yang rendah. Kesukaan masing-masing panelis secara keseluruhan berdasarkan metode uji mutu hedonik dapat digambarkan lebih jelas dengan grafik spider web pada Gambar 4.

Tabel 1. Rataan hasil penilaian organoleptik sari buah pisang tongka langit

\begin{tabular}{cccccc}
\hline Perlakuan lama blansing & Warna & Rasa & Aroma pisang & Aroma langu & Kekeruhan \\
\hline 5 menit & $3,23^{\mathrm{a}}$ & $3,14^{\mathrm{a}}$ & $2,86^{\mathrm{a}}$ & $1,46^{\mathrm{a}}$ & $2,17^{\mathrm{a}}$ \\
10 menit & $2,89^{\mathrm{b}}$ & $2,80^{\mathrm{b}}$ & $2,83^{\mathrm{a}}$ & $1,29^{\mathrm{b}}$ & $1,89^{\mathrm{b}}$ \\
15 menit & $2,83^{\mathrm{c}}$ & $2,66^{\mathrm{b}}$ & $2,8^{\mathrm{ab}}$ & $1,26^{\mathrm{b}}$ & $1,89^{\mathrm{c}}$ \\
20 menit & $2,43^{\mathrm{d}}$ & $2,57^{\mathrm{b}}$ & $2,46^{\mathrm{b}}$ & $1,09^{\mathrm{c}}$ & $1,86^{\mathrm{d}}$ \\
\hline
\end{tabular}

Keterangan: Angka yang diikuti oleh huruf yang sama pada kolom yang sama tidak berbeda berdasarkan uji Tukey 0,05 .

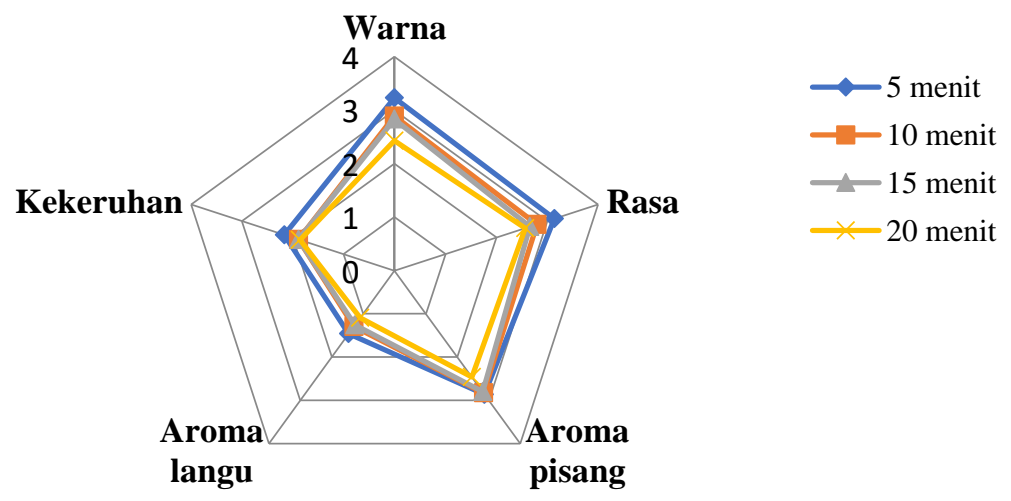

Gambar 4. Rataan penilaian panelis untuk semua sifat inderawi sari buah pisang tongka langit 
Data pada Gambar 4 menunjukkan bahwa perlakuan lama blansing 5 menit memiliki nilai tertinggi untuk semua sifat inderawi yang diuji. Sifat inderawi warna memiliki nilai tertinggi, yaitu warna kuning $(3,23)$, kemudian diikuti oleh sifat inderawi rasa dengan nilai 3,14 (berasa pisang), aroma mendekati beraroma pisang $(2,86)$, kekeruhan agak keruh $(2,17)$, dan tidak beraroma langu $(1,46)$.

\section{KESIMPULAN}

Penerimaan panelis secara keseluruhan berdasarkan pengujian organoleptik dengan metode uji mutu hedonik terdapat pada perlakuan lama blansing 5 menit yang menghasilkan minuman sari buah pisang tongka langit terbaik dengan sifat inderawi sebagai berikut, warna kuning $(3,23)$, berasa pisang $(3,14)$, mendekati beraroma pisang $(2,86)$, agak keruh $(2,17)$, dan tidak beraroma langu $(1,46)$.

\section{DAFTAR PUSTAKA}

Aini, N. 2016. Karakteristik minuman sari buah bligo (Benincasa hispida) dengan penambahan sukrosa pada suhu pasteurisasi yang berbeda. Artikel Fakultas Teknik Universitas Pasundan, Bandung.

Ayu, D.C. dan S.S. Yuwono. 2014. Pengaruh suhu blansing dan lama perendaman terhadap sifat fisik kimia tepung kimpul (Xantyhosoma sagittifolium). Jurnal Pangan Agroindustri 2: 110-120.

Departemen Pendidikan Indonesia. 2008. Kamus Besar Bahasa Indonesia. Balai Pustaka. Jakarta.

Kartika, B., P. Hastuti, dan W. Supartono. 1988. Pedoman Uji Inderawi Bahan Pangan, Edisi Pertama, UGM, Yogyakarta.

Lawalata, V. dan G. Tetelepta. 2017. Pengembangan Olahan Minuman Sari Buah dari Beberapa Jenis Pisang Lokal. Prosiding Seminar Nasional PATPI 2017: Peran Ahli Teknologi Pangan Dalam Mewujudkan Ketahanan Pangan Nasional. November 2017. Lampung.
Mao, L.C., Y.Q. Xu, and F. Que. 2007. Maintaining the quality of sugarcane juice with blanching and ascorbic acid. Food Chemistry 104: 740-745. j.foodchem.2006.09.055

Nasruddin, R. Christiana, dan L. Limantara. 2008. Proyeksi Kebutuhan Vitamin A Tiap Tahun Produk Usia Balita di Indonesia Selama Kurang Waktu 2008-2025 Menurut Ukuran Satuan Berat Basah Wortel (Daucus corata) dan Buah Merah (Pandanus conoidenus). Prosiding Seminar Nasional Pangan: Peningkatan Keamanan Pangan Menuju Pasar Global. Januari 2008. Yogyakarta.

Pujimulyani, D., S. Raharjo., Y. Marsono, dan U. Santoso. 2010. The effects of blanching treatment on the radical scavenging activity of white saffron (Curcuma mangga Val.). International Food Research Journal 17: 615-621.

Puspasari, D.P.W., I.K. Suter, dan K.A. Nocianitri. 2009. Pengaruh penutupan dan suhu pada proses perebusan terhadap karakteristik sirup wortel (Daucus carota L). Agrotekno 15: 25-29.

Samson, E., F.S. Rondonuwu, dan H. Semangun. 2011. Kajian Kandungan Karotenoid Buah Pisang Tongkat Langit (Musa troglodytarum). Prosiding Teknologi Berkelanjutan, Desa Digital Menuju Kedaulatan dan Kesejahteraan Masyarakat, hal. 105-110.

Samson, E., T.A. Edwin, dan D. Wakano. 2013. Analisa Lama Waktu Pemanasan Terhadap Stabilitas Pigmen Karotenoid Buah Pisang Tongka Langit (Musa troglodytarum) Ukuran Panjang. Prosiding. Jurusan Biologi, FMIPA Universitas Pattimura. Ambon.

Setyaningsih, D., A. Apriyantono, dan M.P. Sari. 2010. Analisis Sensori Untuk Industri Pangan dan Agro. IPB Press, Bogor.

Siregar. E.A., H. Rusmarilin, dan L.N. Limbong. 2015. Pengaruh lama blansing dan jumlah gula terhadap mutu manisan basah sawi pahit. Jurnal Rekayasa Pangan dan Pertanian 3: 212-216.

Soekarto, S.T. 1985. Penilaian Organoleptik. Bhantara Karya Aksara. Jakarta. 